\title{
Effect of Organic Manure on the Growth and Yield Performance of Maize in Ishiagu, Ebonyi State, Nigeria
}

\author{
Okoroafor, I. B**, Okelola, E. O, Edeh, O. N emehute, V. C., \\ Onu, C. N.,Nwaneri, T. C. and Chinaka, G. I. \\ Federal College of Agriculture, Ishiagu, Ebonyi State, Nigeria \\ **Corresponding Author.(E-mail: ok.iykeben@yahoo com).
}

\begin{abstract}
The study which aimed at evaluating the effect of organic manure on the growth and yield of maize was conducted at the research and teaching farm of Federal College of Agriculture, Ishiagu in Ivo Local Government Area of Ebonyi State, Nigeria. The experimental design used was randomized complete block design (RCBD) with three treatments each of which was replicated three times, given a total of nine plots measuring $3 m \times 3 m$. The parameters measured were number of leaves, stem girth, plant height and frequency of $c o b$ and weight of cob after harvest. The analysis shows that there were significant difference $(p<0.05)$ among the treatments applied on the parameters measured. It was discovered that treatment 1(Poultry dropping) gave the greatest difference among the treatments. Therefore, based on the findings, poultry dropping is recommended to farmers for optimum growth and yield of maize production.
\end{abstract}

Key words: Organic manure, Growth and Yield.

\section{Introduction}

Agriculture is known to be the oldest industry in the world. Its purpose in the growing of Crops and rearing of animals, all geared towards production of food and feed for man and his live stocks. Over the years, grain yields have depreciated drastically due to the degrading nature of soils, poor fertility management and low import technology to improve the fertility of the soil. The use of organic manure could be adopted ( Gee and Bauder, 1986;Rouant, 1992; Chiefetz et al., 1996) Following geometric increase in population, especially in Nigeria, adequate attention should be directed towards massive and cheapest way of food production. In order to achieve this, emphasis should be laid on the easiest means of enriching our soil and secondly to analyze the key problems which limit production and expansion of crops such as Maize. The problem of inadequate agricultural land to farmers in the Eastern part of Nigeria, ishiagu to be precise, was responsible for continuous cultivation of available land, thereby causing a reduction in outputs. Meanwhile, attempts to use inorganic fertilizer to replenish the soil nutrient have not be successful because of high cost, sometimes, the adulterated nature of the product has adverse effect on the soil, water and plants, hence, there is need to look for other source(s) of maintaining the soil fertility in order to enhance optimum yield maize.

Maize (zea-mays), belongs to the grass family of Gramineae (Gordon 1993), and originated from Central America. It is otherwise known as Corn. According to SAS Institute (1990), Maize is widely grown in both tropical and sub-tropical regions of the world. Popularity of Maize has increased enormously throughout the world. Maize is one of the most domesticated and evolved member of the plant kingdom. It is believed that Maize was introduced into Africa and West Africa by the Portuguese at the beginning of the $16^{\text {th }}$ century (Onwueme 1976). Its grains, which serve as food, feed as well as industrial raw materials contains carbohydrate in form of starch up to $80 \%$ and crude protein up to $10 \%$ (Mangel 1978). Maize is a good source of linolenic acid essential unsaturated fatty acid is also used as feed for humans and animals. In textile industries, zein can be converted to protein- fiber called vicara which is used in blade with wool for manufacturing of sticks, sweater and swimming suits Roth and Fox (1990).

According to Sridhar and Adeoye (2003), Maize has a fibrous rough system which has seminal and prop root in the soil branch repeatedly and spread out. As an annual crop, it has stem, stalk which are solid unbranched and herbaceous where ear bearing branches are formed. Maize can supply human requirement for iron when largely consumed (Whitney 1993).

In Maize production, low soil fertility is one of the limiting factors in Nigeria especially Ebonyi State. Low inputs in agriculture mainly explain the cause of low and declining crop yield in many countries of south Sahara (Simpson et al 1996). The application of N.P.K fertilizer to the soil actually boosts the performance of maize. However, its persistence use destroys soil reaction and impedes the activities of soil micro organisms thereby making the soil acidic and toxic to maize (Omisore 2010). Most importantly, the chemical fertilizer is not affordable to local farmers and so the use of organic manure is of great advantage, because it contains many nutrient required by plant for optimal performance and also helps in improving soil texture and structure. The 
application of organic manure has been found to increase soil $\mathrm{P}^{\mathrm{H}}$ Abam et al ( 2006) and Jinadasa (1997). Organic manure are essential constitute of soil, they are present in variety of forms, ranging from plants and livestock materials. Tivy (1990) while describing the components of organic manure noted that organic manure comprises of waste and residues from crops and livestock. He further reported that farm-yard manure alone is not really capable of returning more than $50 \%$ of the nitrogen, phosphorous and potassium to the soil. The use of organic manure when properly applied, benefits fruiting in plants like maize and generally enhance size, height and number of leaf (Asiegbu and Uzo 1984). Maize tolerates sandy soil, if well supplied with organic materials. On the heavier soil, the yields are usually large and bearing period longer than the lighter soil. It is cultivated extensively in the northern, as well as the southern parts of Nigeria. Though, a major product of small scale farmers in Nigeria, the production of maize has increased to 1220 metric tons (FAO, 2006). Lucas (1986), maintained that the application of some organic manure might be more important than the addition of chemical fertilizer.

\section{Materials And Methods}

This research work was conducted in research and teaching farm of Federal College of Agriculture, Ishiagu, Ebonyi State Nigeria.(latitude $5^{0} 55^{\mathrm{ll}} \mathrm{S}$, longitude $7^{0} 31^{11} \mathrm{E}$ ) in the derived Savannah zone, with mean annual rainfall of $1735.7 \mathrm{~mm}$ and annual temperature of about $29.4^{0 \mathrm{C}}$ and relative humidity of about $67 \%$ during dry season and about $91 \%$ during rainy season (FCAI, 2003). The variety of maize seed used was Oba Super II which was obtained from Federal College of Agriculture, Ishiagu. Viability test was conducted to ascertain that the seeds were viable at $95 \%$. The treatments applied for the study were poultry dropping and pig dung, which were also collected from the College farm and control. The data collected were analyzed using ANOVA. The parameters measured include; maize leaves, stem girth, plant height at 3, 5, 7 and 9 weeks after planting and the number of cob and weight of fresh maize after harvesting.

Land preparation, planting materials and methods The study started in June and ended in August, 2011 with a total experimental area of $15 \mathrm{~m}$ by $13 \mathrm{~m}(195 \mathrm{~m} 2)$. The land was cleared, ploughed, tilled and marked into three (3) blocks and three (3) beds each measuring $3 \mathrm{mx} 3 \mathrm{~m}\left(9 \mathrm{~m}^{2}\right)$ were made in each block, making a total of 9 beds. Inter block and inter bed distance of $1 \mathrm{~m}$ was used. The seeds were planted two (2) per hole at the depth of $2 \mathrm{~cm}$ with a spacing of $75 \mathrm{~cm} \times 25 \mathrm{~cm}$. Randomized complete block design (RCBD) was used for the study, and the treatments were each replicated three (3) times. The treatments used are: $20 \mathrm{~kg}$ of Poultry dropping $\left(\mathrm{T}_{1}\right)$, $20 \mathrm{~kg}$ of Pig Dung $\left(\mathrm{T}_{2}\right)$ and control or no treatment $\left(\mathrm{T}_{3}\right)$

\section{Result And Discussions}

Table 1 shows the result of pre- planting soil analysis carried out. It indicates that the soil is low in nitrogen content, organic matter, available phosphorous exchangeable base, organic carbon and effective caution exchange capacity (FMANR, 1990). This implies that the soil is poor in nutrients and of low productivity. Hence response to organic manure would be encouraged Agbogidi and Okonmah (2012).

Table 2 shows the mean number of maize leaves at 3WAP, 5WAP, 7WAP and 9WAP. The Table reveals that treatment 1 (poultry dropping) gave the highest mean number of maize leaves across the weeks, this was followed by the treatment 2 (pig dung) while treatment 3 (control) gave the least mean number of maize leaves. The result shows that there significant difference $(\mathrm{p}<0.05)$ among the treatments which agrees with the findings of SAS Institute (1990) who reported that poultry droppings has high nitrogen and phosphorous which is highly needed by maize, thereby increasing the growth and leaf number of maize.

Table 3 shows stem girth of maize at 3WAP, 5WAP, 7WAP and 9WAP. The result shows that treatment 1 (poultry dropping) gave the highest mean stem girth of maize across the weeks, while treatment 3 (control) gave the least mean stem girth of maize across the weeks. The result reveals that there were significant difference $(p<0.05)$ among the treatments. This agrees with the finding of Anon (2002) who opined that organic manure is an excellent fertilizer material because of its high nitrogen, phosphorous and potassium contact and it is readily available than the mineral fertilizer and its effect on the soil is stable, slow in releasing nutrition to crop and also improving the soil physical and chemical properties.

Table 4 shows the mean plant height of maize at 3WAP, 5WAP, 7WAP and 9WAP. The result indicates that treatment 1 which is poultry dropping gave the highest mean plant height across the weeks. This was followed by pig dung while control which is treatment 3 gave the least mean plant height. The Table also revealed that there were significant difference $(\mathrm{p}<0.05)$ among the treatments. This agrees with the assertion of Olatunji et al (2006) lay credence to this claim where okra and tomatoes grown in poultry manure performed better than their counterparts in other manure types. Table 5 shows the mean number of maize cob and weight of fresh maize $(\mathrm{kg})$ after harvesting. The result revealed that treatment 1; poultry dropping gave the highest mean number of maize cob and weight of fresh maize $(\mathrm{kg})$ after harvest, followed by pig dung (treatment 2) while control (treatment 3 ) gave the least mean number of maize cob and weight of fresh maize. This also indicated that there were significant difference $(\mathrm{p}<0.05)$ among the treatments. However, this was in line with the finding 
Effect Of Organic Manure On The Growth And Yield Performance Of Maize In Ishiagu, Ebonyi State,

of Windham (1969) that organic manure like poultry dropping improves the structure of the soil thereby increasing the vegetative growth as well as the size and number of fruits.

\section{Conclusion}

This study shows that the use of organic manure (poultry dropping) improves the chemical and physical properties of the soil, thereby increasing the growth and yield of maize. The application of organic manure highly increase plant height, number of maize leaves, stem girth, number of cob and weight of fresh maize at harvest.

Table 1: Pre - Planting Soil Analysis.

\begin{tabular}{|c|c|}
\hline Sand $(\%)$ & 40.2 \\
\hline Silt (\%) & 3.8 \\
\hline Clay $(\%)$ & 3.4 \\
\hline Soil PH & 4.72 \\
\hline \multicolumn{2}{|l|}{ Textural class } \\
\hline Organic Carbon (\%) & 0.89 \\
\hline Organic Matter $\left(\mathrm{gkg}^{-1}\right)$ & 2.53 \\
\hline Total Nitrogen $(\%)$ & 0.09 \\
\hline Available P (mgka) & 35.20 \\
\hline $\mathrm{Ca}^{2+}(\mathrm{emol} / \mathrm{kg}$ & 1.48 \\
\hline $\mathrm{Mg}^{2+}(\mathrm{emol} / \mathrm{kg}$ & 0.19 \\
\hline $\mathrm{Na}^{+}$ & 0.30 \\
\hline $\mathrm{K}^{+}$ & 0.20 \\
\hline $\mathrm{H}^{+}$ & 0.52 \\
\hline $\mathrm{Al}^{3+}$ & 0.05 \\
\hline ECEC & 2.20 \\
\hline Base Saturation (\%) & 72.40 \\
\hline
\end{tabular}

Table 2: The Effect of the Treatments on the Mean Number of Maize Leaves.

\begin{tabular}{cclcl} 
Treatment & 3 WAP & 5WAP & 7WAP & 9 WAP \\
\hline $\mathrm{T}_{1}$ & 7.40 & 10.36 & 14.51 & 15.37 \\
$\mathrm{~T}_{2}$ & 6.68 & 9.98 & 12.10 & 14.57 \\
$\mathrm{~T}_{3}$ & 6.37 & 7.72 & 11.2 & 13.03 \\
$\operatorname{LSD}(0.05)$ & $0.16^{* *}$ & $0.29^{* *}$ & $0.38^{* *}$ & $1.77^{* *}$ \\
\hline
\end{tabular}

** Significant at $5 \%$ alpha level.

Table 3: The Effect of the Treatments on the Mean Stem Girth of Maize.

\begin{tabular}{ccccc} 
Treatment & 3 WAP & 5 WAP & 7 WAP & 9 WAP \\
\hline $\mathrm{T}_{1}$ & 4.24 & 8.02 & 7.47 & 6.62 \\
$\mathrm{~T}_{2}$ & 4.22 & 6.92 & 7.67 & 6.34 \\
$\mathrm{~T}_{3}$ & 3.23 & 5.07 & 5.05 & 4.57 \\
$\mathrm{LSD}(0.05)$ & $0.8392^{* *}$ & $0.37^{* *}$ & $0.76^{* *}$ & $1.029^{* *}$ \\
\hline
\end{tabular}

** Significant at $5 \%$ alpha level.

Table 4: The Effect of the Treatments on the Mean Plant Height of Maize.

\begin{tabular}{ccccc} 
Treatment & 3 WAP & 5 WAP & 7WAP & 9WAP \\
\hline $\mathrm{T}_{1}$ & 32.09 & 87.74 & 197.43 & 226.68 \\
$\mathrm{~T}_{2}$ & 29.55 & 78.63 & 174.33 & 169.80 \\
$\mathrm{~T}_{3}$ & 23.21 & 62.31 & 102.20 & 169.12 \\
$\operatorname{LSD}(0.05)$ & $7.7521^{* *}$ & $10.54^{* *}$ & $63.94^{* *}$ & $13.9^{* *}$ \\
\hline
\end{tabular}

**Significant at 5\% alpha level.

Table 5: The Effect of the Treatments on the Mean Number of Maize Cob and Mean Weight of Fresh Maize (kg) After Harvest.

\begin{tabular}{ccc} 
Treatment & Mean number of Maize & Mean Weight of Fresh Maize Cob \\
\hline $\mathrm{T}_{1}$ & 13.17 & 3.83 \\
$\mathrm{~T}_{2}$ & 12.73 & 2.67 \\
$\mathrm{~T}_{3}$ & 12.17 & 2.57 \\
$\mathrm{LSD}(0.05)$ & $0.36^{* *}$ & $0.31^{* *}$ \\
** Significant at 5\% alpha level.
\end{tabular}




\section{Reference}

[1]. Abam, P. O., I. N. Onyekwere and K. I Nwosu (2006). Properties and Management of OG Oj soils Cross River State, Nigeria for increased cassava yield, Proceedings of the $40^{\text {th }}$ conference of Agriculture Society of Nigeria, pp346- 349.

[2]. Agbogidi, O. M, and Okonmah, C. U. (2012), "Growth and Yield of Maize as Influenced by Organic Manure type in a Niger Delta Environment”. International Journals of Agriculture and Rural Development (IJARD) vol. 15 (1) 2012 Owerri, pp 818 - 824.

[3]. Anon (2002), “Agriculture issue on compost controversy”. Acres U.S.A, June, p 20

[4]. Asiegbu and Uzo (1984). Evaluation principle in Fertilizer pp 50.

[5]. Chiefez, B., Hatcher, P., Hadar, Y. and Chen, Y. (1996). Chemical and Biological Characterization of Organic and Municipal solid waste. Environmental Quality 25:776-785.

[6]. FCAI, (2003), "Year Bulletin, Meteorology and Weather". Federal College of Agriculture, Ishiagu, Ebonyi State Nigeria.

[7]. FMANR (1990). Literature on soil fertility investigation in Nigeria. A bulletin produced by the Federal Ministry of Agriculture and Natural Resources. Lagos p40

[8]. FAO (Food and Agriculture Organization, 1995), Production Year book vol. 50 Rome, Italy.

[9]. Gee, G. W. and Bauder, J. W. (1986). Maize Research and Production in Nigeria Institute of Agriculture. Moor Plantation. Ibadan, Nigeria.

[10]. Gordon, N. B. and Whitney (1993), Nitrogen Management in Furrow Irrigated Ridge Tilled Corn. Journal of Production Agriculture. Vol. 6, pp $213-217$.

[11]. Jinadsa, K.B, P. N. Miham, C. A. Hakins, P. S. Cornish, P. A. Williams, C. J. Kaldo and J. P. Conroy (1997). Survey of cadinium levels in vegetable and soils of Greater Sydney Australian Journal of Environmental Quality No 4 pp185-198.

[12]. Lucas, E. O. (1986); Effect of Density and Nitrogen Fertilizer on the Growth and Yield of Maize in Nigeria. Journal of Agricultural Science, vol. 107, pp573 - 578.

[13]. Mangel (1978), "Principles of Plant Nutrient". International Potash Institute, Borne, Switzerland.

[14]. Olatunji, U. S., Ayuba, A. and Oboh V. U. (2006). Growth and yield of Okra and Tomatoes as affected by pig dung and other organic manure. American Jorunal of Plant Physiology1 (2):78-85

[15]. Omisore, (2001); Effect of Fertilizer Application

[16]. Onwueme, I. C. (1978); Crop Science Cassed Ltd. Pp 166

[17]. Roth, G. W. and Fox, R. H (1990), "Soil Nitrate Accumulation following Nitrogen Fertilizer Corn". in Pennsy Environment Quall vol. 19, pp $243-248$.

[18]. SAS Institute (1990), SAS User Guide Statistics SAS Institute Cary Ne.

[19]. Simpson (1986) Fertilizer and Manure Longman Group Publishers, Honkong pp 156.

[20]. Sridhar, M. K. C. and Adeoye, G.O. (2003). “Organic Minerals Fertilizer from Urban Waste the Nigeria Field vol. 68, pp 91 111.

[21]. Tivy,(1990); “Agricultural Ecology” Longman Group Ltd. United Kingdom.

[22]. Windham, L. (1969); Okra fertility Spacing Study, Hort Abstract. Vol. 40, pp156. 